\title{
Monoclonal antibodies to the exon 18 encoded moiety of NCAM
}

\author{
Ann Vander Borght ${ }^{1,2}$, Mieke Duysinx², Monique Ummelen ${ }^{1}$, Bernard A.M. van der Zeijst ${ }^{3}$ \\ 'Department of Genetics and Cell Biology and GROW School for Oncology and Developmental Biology, Maastricht University, \\ Maastricht, PO Box 616, 6200 MD, The Netherlands. \\ ${ }^{2}$ MUbio Products B.V., Maastricht, 6200 EV, The Netherlands. \\ ${ }^{3}$ Catherinn B.V., Manuel de Fallapad 1, Rotterdam, 3069 MR, The Netherlands.
}

Correspondence to: Prof. Bernard A.M. van der Zeijst, Catherinn B.V., Manuel de Fallapad 1, Rotterdam, 3069 MR, The Netherlands. E-mail: zeijst@lumc.nl

How to cite this article: Vander Borght A, Duysinx M, Ummelen M, van der Zeijst BAM . Monoclonal antibodies to the exon 18 encoded moiety of NCAM. J Cancer Metastasis and Treatment 2019;5:57. http://dx.doi.org/10.20517/2394-4722.2019.0010

Received: 15 Jan 2019 First Decision: 13 Apr 2019 Revised: 15 Apr 2019 Accepted: 21 May 2019 Published: 20 Jul 2019

Science Editor: Ira-Ida Skvortsova Copy Editor: Han-Juan Zhang Production Editor: Jing Yu

\begin{abstract}
Aim: Exon 18 expression of NCAM has been recognized as a biomarker for small cell lung cancer (SCLC). To use this finding for an improved diagnosis of SCLC and personalized treatment of patients, techniques to identify and quantitate E18, the exon 18 encoded protein moiety of NCAM, are needed. We developed three monoclonal antibodies for this purpose.
\end{abstract}

Methods: The his-tagged E18 antigen was expressed in E. coli and, after purification, used to immunize mice. Hybridoma's were isolated by standard procedures and tested for their reaction with E18.

Results: Three monoclonal antibodies, MUM-1, MUM-4 and MUM-6 were obtained. They reacted with E18 in western blots, with SCLC cell line $\mathrm{NCl}-\mathrm{H} 82$, but not with unrelated his-tagged proteins. Only permeabilized $\mathrm{NCl}-\mathrm{H} 82$ cells stained with the antibodies, confirming the intracellular position of E18. Next an enzyme-linked immunosorbent assay was developed using the earlier isolated monoclonal antibody MUMi-21B2, coated on the surface of microtiter wells as capture antibody and biotinylated MUM-6 as second antibody. Using streptavidin conjugated to horse radish peroxidase a linear dose response curve to his-tagged $\mathrm{E} 18$ antigen was obtained between 0 and $5 \mu \mathrm{g} / \mathrm{mL}$ with a sensitivity of at least $0.5 \mu \mathrm{g} / \mathrm{mL}$ or $50 \mathrm{ng} /$ well.

Conclusion: Four monoclonal antibodies are available to be used in assays for the identification and quantification of SCLC biomarker E18. This will enable the development of liquid biopsies to follow the tumor load in patients.

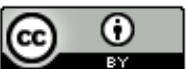

(C) The Author(s) 2019. Open Access This article is licensed under a Creative Commons Attribution 4.0 International License (https://creativecommons.org/licenses/by/4.0/), which permits unrestricted use, sharing, adaptation, distribution and reproduction in any medium or format, for any purpose, even commercially, as long as you give appropriate credit to the original author(s) and the source, provide a link to the Creative Commons license, and indicate if changes were made.

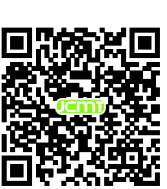


Keywords: Small cell lung cancer, tumor biomarker, monoclonal antibodies, NCAM exon 18

\section{INTRODUCTION}

Small cell lung cancer (SCLC) is strongly associated with smoking. It is a very aggressive form of cancer due to resistance to chemotherapy and rapidly dividing metastatic disseminations. SCLC represent about $15 \%$ of all lung cancer cases and annually kills about 250,000 people ${ }^{[1]}$. At the initial diagnosis metastatic lesions are already present in about two thirds of the patients ${ }^{[2]}$. Patients die as a result of the disease at a median of 10 to 12 months after diagnosis ${ }^{[3]}$. Over many decades survival rates have not improved ${ }^{[4]}$. SCLC is a neuroendocrine tumor. There are three other types of neuroendocrine lung tumors [Table 1]. A hallmark of these tumors is the presence of neuroendocrine peptides such as NCAM. NCAM is expressed as 120, 140 and $180 \mathrm{kDa}$ isoforms, all derived through alternative splicing from a single gene. NCAM has been described as a biomarker for SCLC, but is also present on other cell types ${ }^{[5]}$.

Biomarkers for SCLC could lead to an important improvement in the treatment of SCLC. These markers could be used to monitor the tumor load in patients, allowing early diagnosis and monitoring the effect of therapeutic interventions. We recently described the expression of NCAM exon 18 as a potential biomarker for SCLC ${ }^{[5]}$. More recently we have further validated this biomarker. More SCLC biopsies were tested. These were all positive for NCAM exon 18 expression. Expression was also found in large cell neuroendocrine carcinoma (LCNEC) (unpublished data). In this paper we describe the generation and characterization of monoclonal antibodies directed to E18, the exon 18 encoded moiety of NCAM. We intend to use these antibodies for the quantification of E18 in extracellular vesicles present in the blood of SCLC patients.

\section{METHODS}

\section{Production of monoclonal antibodies}

\section{Preparation of antigen}

Recombinant his-tagged E18 was prepared in E. coli, using a plasmid with a codon usage optimized for E. coli (GeneArt/Thermo Fisher Scientific), and purified on a $\mathrm{Ni}^{2+}$-NTA agarose column and E18-encoding DNA was cloned into the $\mathrm{pCI}$ mammalian expression vector as described ${ }^{[5]}$.

\section{Immunization of mice and preparation of hybridoma's}

Three Balb/c mice were immunized 4 times. At zero time intramuscularly with 2 times $50 \mu \mathrm{g}$ in $50 \mu \mathrm{L}$ of the pCI vector containing E18-encoding DNA and at 3 and 8 weeks subcutaneously with $10 \mu \mathrm{g}$ his-tagged E18 and $12 \mu \mathrm{g}$ (in $25 \mu \mathrm{L}$ ) AbISCO-100 (Isconova, Sweden). The final immunization was at 10 weeks with $10 \mu \mathrm{g}$ his-tagged E18 without adjuvant subcutaneously and the same amount intraperitoneally. Three days after the last immunization spleen cells were isolated and fused with $\mathrm{SP} 2 / 0$ myeloma cells according standard procedures $^{[9]}$. Cells were plated in nine 96 well microtiter plates.

\section{Screening and characterization}

The supernatants of the microtiter wells were tested in an enzyme-linked immunosorbent assay (ELISA) as described ${ }^{[5]}$. Wells were coated with his-tagged E18 or an unrelated his-tagged protein. This resulted in 6 candidates positive for E18 and negative for unrelated his-tagged proteins. These hybridoma's were subcloned and characterized by four methods. First, an ELISA was carried out on full length E18 and a shortened version of E18 (Supplementary Figure 1 by Vander Borght et al. ${ }^{[5]}$ ). Second, immunohistochemistry on SCLC cell line NCI-H82 and control cell line HCT116. Third flow cytometry of intact and permeabilized NCI-H82 cells and last western blotting. Experimental details can be found in the study by Vander Borght et al. ${ }^{[5]}$. Isotyping was carried out with the MMT1 kit of AdD Serotec (presently Biorad). 
Table 1. Neuroendocrine tumors of the lung

\begin{tabular}{|c|c|c|c|c|c|}
\hline Name & Smoking-associated & $\%$ of all cases of lung cancer & Overall Survival 5 y & Mitotic index ${ }^{\star}$ & Ki-67 index ${ }^{\#}$ \\
\hline$\overline{\mathrm{SCLC}}$ & Yes & $15-20$ & $<5 \%$ & Median $=80$ & $50 \%-100 \%$ \\
\hline LCNEC & Yes & 3 & $15 \%-57 \%$ & Median $=70$ & $40 \%-80 \%$ \\
\hline TC & No & $1-2$ & $92 \%-100 \%$ & $<2$ & $<5 \%$ \\
\hline$A C$ & No & $0.1-0.2$ & $61 \%-68 \%$ & $2-10$ & $<20 \%$ \\
\hline
\end{tabular}

Data from Ref.[6,8]. *Measure for rate of cell division; ${ }^{\#}$ Ki-67 is a marker protein for cell division. SCLC: small cell lung cancer; LCNEC: large cell neuroendocrine carcinoma; TC: typical carcinoid; AC: atypical carcinoid.

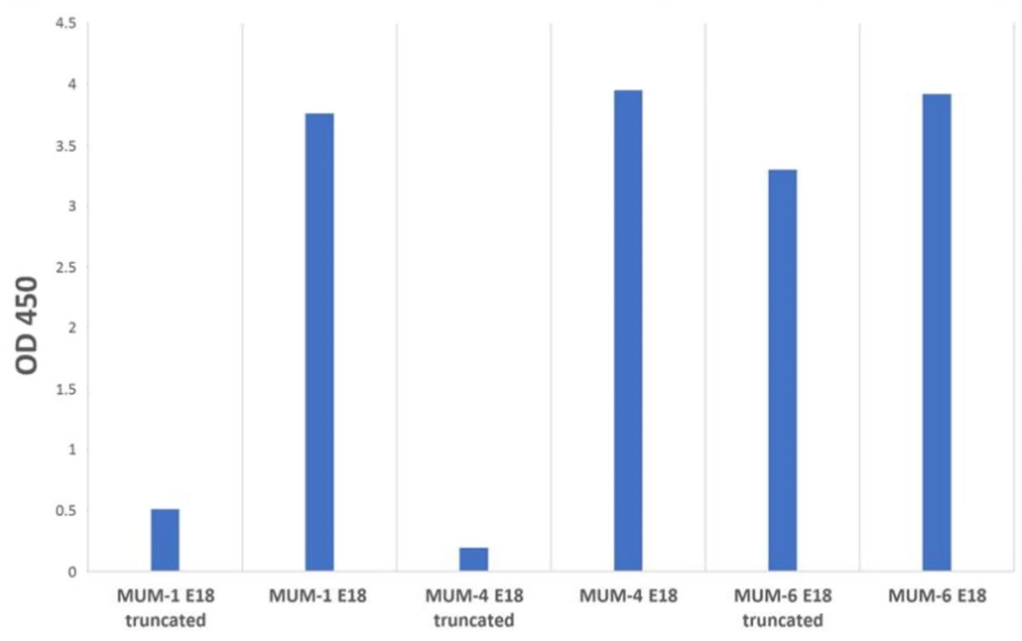

Figure 1. Reaction of monoclonal antibodies MUM-1, MUM-4 an MUM- 6 with (truncated) E18 measured by an ELISA

\section{Setting up of an ELISA}

An ELISA was set up, using one antibody coated to the microtiter wells as a capture antibody and a second biotinylated antibody for detection. The best combination of antibodies was MUMi-21B2 as a capture antibody and MUM-6 as second antibody. Full experimental details can be found in Supplementary Figure 1.

\section{RESULTS}

Three monoclonal antibodies, MUM-1 (IgG1 kappa), MUM-4 (IgG1 kappa) and MUM-6 (IgG1 lambda), were fully characterized and produced. The ELISA confirmed that they all react with E18. MUM-6 also reacted with the truncated form of E18 that was used to generate MUMi-21B2 [Figure 1].

The monoclonal antibodies were also tested in immunohistochemistry assays on SCLC cell line NCI-H82 and control colon carcinoma cell line HCT116. In comparison antibody RNL-1, directed to an extracellular part of NCAM, was used. Figure 2 shows the results for MUM-4 and MUM-6. A strong reaction of RNL-1 to NCI-H82 cells an no reaction to HCT116 cells that lack NCAM is seen. The signal with MUM-4 and MUM6 is weaker but clearly present. A stronger signal was obtained when the cells were permeabilized with $4 \%$ paraformaldehyde/0.5\% triton X-100 (data not shown). Intact cells did not stain with the MUM-1, MUM-4 and MUM-6. This could be demonstrated most convincingly by flow cytometry. The results for MUM-1 are shown in Figure 3.

\section{DISCUSSION}

The further validation of NCAM exon 18 expression in cancer cells is ongoing. More SCLC and LCNEC biopsies will be analyzed. These are the two most aggressive neuroendocrine lung cancers, but it will be also of interest to analyze the milder [Table 1] "typical carcinoid" and "atypical carcinoid". However, our focus 

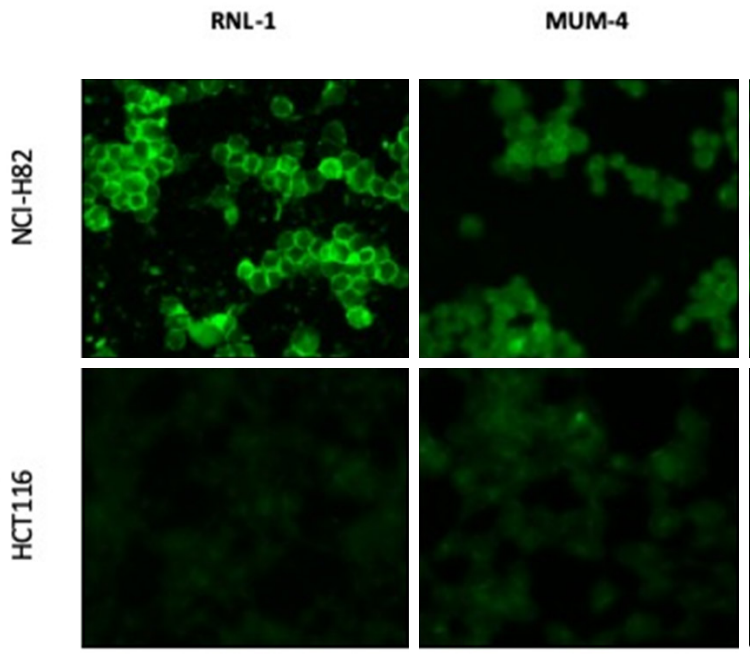

MUM-6

Figure 2. Immunohistochemistry of SCLC cell line $\mathrm{NCl}-\mathrm{H} 82$ and colon carcinoma cell line HCT116. The results for MUM-4 and MUM-6 are shown, together with the staining with RNL-1, a monoclonal antibody directed to an extracellular part of NCAM. Cells were permeabilized with methanol/acetone as described ${ }^{[5]}$ or, for the MUM-6 panel, with $4 \%$ paraformaldehyde (15 min) and $0.5 \%$ Triton-X100 (10 min)

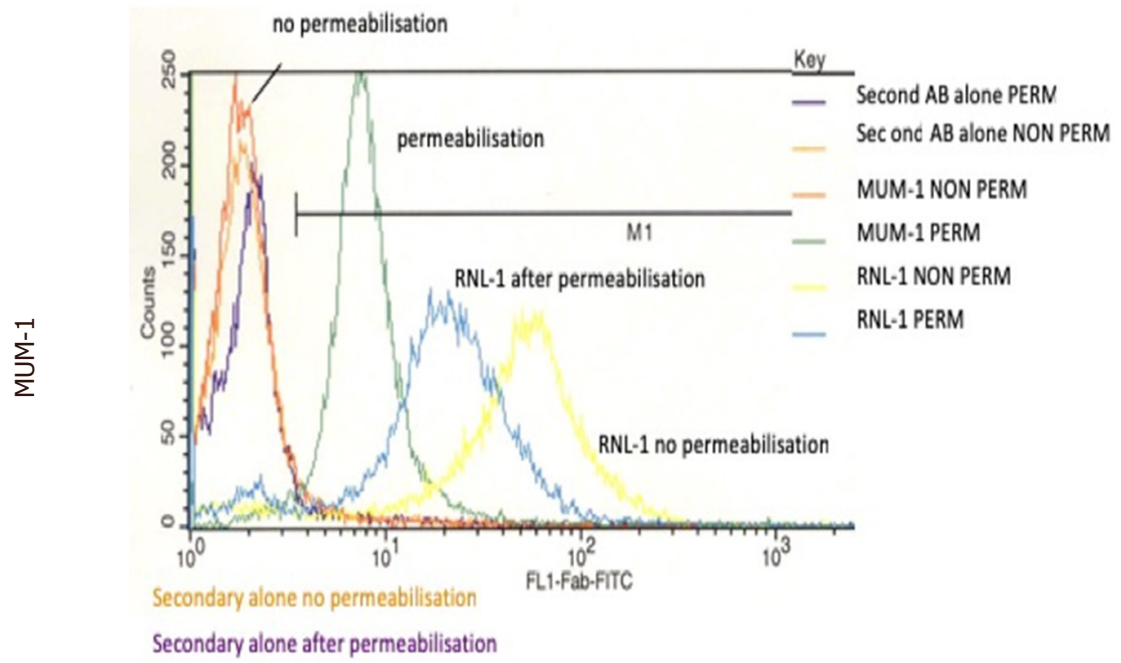

Figure 3. Reaction of MUM-1 with SCLC cell line $\mathrm{NCl}-\mathrm{H} 82$ measured with flow cytometry. Methanol/acetone permeabilized cells were compared with intact cells. A signal was only found in permeabilized cells. This difference was not found with antibody RNL-1 directed to an external region of NCAM

will be on clinical applications of E18 as a biomarker for SCLC. A main problem in the treatment of SCLC is that patients initially respond well to first line chemotherapy, even in advanced disease, but most patients relapse within 6 months. Promising alternative targeted and immune therapies have been identified ${ }^{[10-12]}$, but due to the rapid progression of the disease the time window to study these alternatives is limited. Ideally clinical treatment should be guided by closely monitoring the evolution of the disease $\mathrm{i}^{[12,13]}$. Our assumption is that the presence of E18 will reflect the tumor load. We intend to develop methods to analyze the presence of E18 in liquid biopsies. Serial sampling would give information on disease burden, responses to treatment and on disease relapse. Promising results have been obtained with circulating tumor cells (CTCs $)^{[14]}$, but there is a large variation in CTC numbers and heterogeneity in the expression of NCAM ${ }^{[14]}$. Our present strategy is to use tumor derived extracellular vesicles (EVs) as a correlate of tumor load. EVs are constantly formed by cells, either from endosomal membrane compartments (exosomes) or from the 


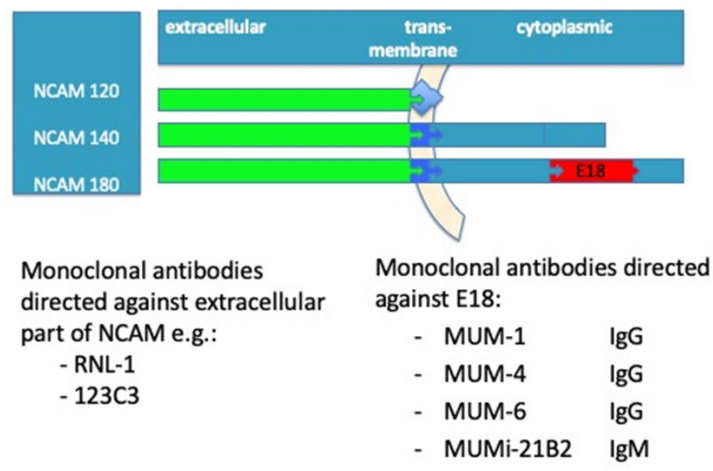

Figure 4. Strategy for the isolation of extracellular vesicles (EVs) derived from SCLC cells. SCLC-specific EVs are enriched and purified by RNL-1 and/or $123 \mathrm{C}$ antibodies, specific for the extracellular moiety of $\mathrm{NCAM}^{[19-21]}$, coupled to magnetic beads. In the next step the presence of $\mathrm{E} 18$ in the EVs will be measured with one of the specific antibodies. We will choose the antibody with the best signal to noise ratio

plasma membrane. The membranes of EVs contain in principle all cellular surface proteins and, within the membrane, all cytoplasmic components ${ }^{[15]}$. Virtually all SCLC cells express NCAM $^{[16,17]}$. We will enrich for NCAM-containing EVs, using immunoaffinity capture methods ${ }^{[18]}$ [Figure 4].

\section{DECLARATIONS}

\section{Authors' contributions}

Design and execution of experiments: Vander Borght A, Duysinx M, Ummelen M

Manuscript drafting, literature analysis and research strategy: van der Zeijst BAM

\section{Availability of data and materials}

Not applicable.

\section{Financial support and sponsorship}

None.

\section{Conflicts of interest}

All authors declared that there are no conflicts of interest.

\section{Ethical approval and consent to participate}

The animal experiments were carried out at the University of Maastricht, and were approved by the Animal Experiments Committee of the University of Maastricht (project number 2005-043).

\section{Consent for publication}

Not applicable.

\section{Copyright}

(c) The Author(s) 2019.

\section{REFERENCES}

1. Gazdar AF, Bunn PA, Minna JD. Small-cell lung cancer: what we know, what we need to know and the path forward. Nat Rev Cancer 2017; $17: 765$.

2. van Meerbeeck JP, Fennell DA, De Ruysscher DK. Small-cell lung cancer. Lancet 2011;378:1741-55.

3. Rudin CM, Ismaila N, Hann CL, Malhotra N, Movsas B, et al. Treatment of small-cell lung cancer: American society of clinical oncology endorsement of the American college of chest physicians guideline. J Clin Oncol 2015;33:4106-11. 
4. Lally BE, Urbanic JJ, Blackstock AW, Miller AA, Perry MC. Small cell lung cancer: have we made any progress over the last 25 years? Oncol 2007;12:1096-104.

5. Vander Borght A, Duysinx M, Broers JLV, Ummelen M, Falkenberg FW, et al. The 180 splice variant of NCAM-containing exon 18-is specifically expressed in small cell lung cancer cells. Transl Lung Cancer Res 2018;7:376-88.

6. Kim JY, Hong SM, Ro JY. Recent updates on grading and classification of neuroendocrine tumors. Ann Diagn Pathol 2017;29:11-6.

7. Rekhtman N. Neuroendocrine tumors of the lung: an update. Arch Pathol Lab Med 2010;134:1628-38.

8. Travis WD. Advances in neuroendocrine lung tumors. Ann Oncol 2010;21 Suppl 7:vii65-71.

9. Lane RD. A short-duration polyethylene glycol fusion technique for increasing production of monoclonal antibody-secreting hybridomas. J Immunol Methods 1985;81:223-8.

10. Lehman JM, Gwin ME, Massion PP. Immunotherapy and targeted therapy for small cell lung cancer: there is hope. Curr Oncol Rep 2017;19:49.

11. Mamdani H, Induru R, Jalal SI. Novel therapies in small cell lung cancer. Transl Lung Cancer Res 2015;4:533-44.

12. Hendriks LEL, Menis J, Reck M. Prospects of targeted and immune therapies in SCLC. Expert Rev Anticancer Ther 2018;28:1-17.

13. Almodovar K, Iams WT, Meador CB, Zhao Z, York S, et al. Longitudinal cell-free DNA analysis in patients with small cell lung cancer reveals dynamic insights into treatment efficacy and disease relapse. J Thorac Oncol 2018;13:112-23.

14. Foy V, Fernandez-Gutierrez F, Faivre-Finn C, Dive C, Blackhall F. The clinical utility of circulating tumour cells in patients with small cell lung cancer. Transl Lung Cancer Res 2017;6:409-17.

15. Choi DS, Kim DK, Kim YK, Gho YS. Proteomics of extracellular vesicles: exosomes and ectosomes. Mass Spectrom Rev 2015;34:47490.

16. Kaufmann O, Georgi T, Dietel M. Utility of 123C3 monoclonal antibody against CD56 (NCAM) for the diagnosis of small cell carcinomas on paraffin sections. Hum Pathol 1997;28:1373-8.

17. Kibbelaar RE, Moolenaar KE, Michalides RJ, Van Bodegom PC, Vanderschueren RG, et al. Neural cell adhesion molecule expression, neuroendocrine differentiation and prognosis in lung carcinoma. Eur J Cancer 1991;27:431-5.

18. Greening DW, Xu R, Ji H, Tauro BJ, Simpson RJ. A protocol for exosome isolation and characterization: evaluation of ultracentrifugation, density-gradient separation, and immunoaffinity capture methods. Methods Mol Biol 2015;1295:179-209.

19. Boerman OC, Mijnheere EP, Broers JL, Vooijs GP, Ramaekers FC. Biodistribution of a monoclonal antibody (RNL-1) against the neural cell adhesion molecule (NCAM) in athymic mice bearing human small-cell lung-cancer xenografts. Int J Cancer 1991;48:457-62.

20. Schol DJ, Mooi WJ, van der Gugten AA, Wagenaar SS, Hilgers J. Monoclonal antibody 123C3, identifying small cell carcinoma phenotype in lung tumours, recognizes mainly, but not exclusively, endocrine and neuron-supporting normal tissues. Int J Cancer Suppl 1988;2:34-40.

21. Gerardy-Schahn R, Eckhardt M, Ledermann J, Kemshead JT. Topography of NCAM antigenic epitopes recognized by SCLC-cluster-1 antibodies. A consensus view. Int J Cancer Suppl 1994;8:27-9. 